\title{
抗菌，抗ウイルス，抗バイオフィルムとその表面処理動向
}

\author{
伴雅 人 ${ }^{\mathrm{a}}$
}

${ }^{a}$ 日本工業大学 基幹工学部 応用化学科 ( $\bar{T} 345-8501$ 埼玉県南埼玉郡宮代町学園台 4-1)

\section{Trends of Antibacterial, Antivirus and Antibiofilm Surface Treatments}

\section{Masahito BAN ${ }^{a}$}

${ }^{a}$ Department of Applied Chemistry, Faculty of Fundamental Engineering, Nippon Institute of Technology (4-1 Gakuendai, Miyashiro, Minami-Saitama, Saitama 345-8501)

\section{Keywords : Antibacterial, Antivirus, Antibiofilm, Surface Treatment}

\section{1.はじめに}

COVID-19によるパンデミックが，我々の生活だけでなく， 仕事や人生観に対する意識にまで影響を与えている。このよ うな自然災害に直面することによって, 人類が, サイエンス やエンジニアリングを拠り所とする対策が唯一感染症を抑え ることができるという共通認識を今回体得したことは, ある 意味，今後の世界を考えると不幸中の幸いであろう。グロー バル化と地球温暖化が進む中, 我々は, ウイルスや細菌によ る新興・再興感染症が今後も再び引き起こされることを想定 し, その感染防止のための科学・技術的対策を, 契緊に押し 進める必要がある。感染経路の一つである接触感染は, モノ を間に挟んだヒトーモノーヒト感染であり, 感染者の唾液な どにより污染された環境(モノの表面)に触れることから起こ る。そのため, 感染防止のためには, モノの表面の細菌やウ イルスによる污染を防ぐ技術, すなわち, 抗菌・抗ウイルス 表面処理技術が重要な意味をもつ。一方, 細菌による感染が そのパフォーマンスを顕著に低下させる重大な問題となるも のとして, 整形外科用人工器具や, 尿道や血管用カテーテル などの内在性の医療器具がある。細菌の付着は, それらの器 具へのバイオフィルムの形成を誘導する。また, 多くの抗生 物質に耐性をもつ多剂耐性菌がイ夕チごっことなりながら出 現しており，この連鎖を断ち切るためにも抗生物質に頼る必 要のない技術, すなわち, これらの器具自体に抗菌スペクト ラムの広い表面処理を施す技術の出現が待たれる。

2008 年に設立された抗菌製品技術協議会 (SIAA) は, この ような抗菌・抗ウイルス・抗バイオフィルム処理を施した加 工製品に対し, 評価基準を策定し認証を行うなど, 活発な活 動を行なってきている。これにより, 国内だけでなく世界に 向けて高品質で安全性のある抗菌・抗ウイルス加工製品が市 場に送り出されており, SIAAの活動が感染症防止に対しグ ローバルに貢献しているといえるであろう。

本稿では, 現在そして今後の世界における感染防止対策の ための重要な柱の一つとなる, 抗菌・抗ウイルス・抗バイオ
フィルム表面処理技術について概説する。より具体的には, 細菌やウイルス, バイオフィルムの構造やその材料表面での 様態, そして, それらの増殖や成長を抑えるための材料表面 設計の指針と方策を述べ，さらに，そのような表面をさまざ まな材料や手法にて形成した研究について, その動向がわか るようになるべく多くの例をあげて説明する。

\section{2. 細菌・ウイルス・バイオフィルム}

生物界は, 細菌, アーキアおよび真核生物の 3 つのドメイ ンに分類される。細菌は, 細胞に核膜がある動植物などの真 核生物とは異なり，核膜を持たず，別のドメインに分類され る。一方, ウイルスは, この 3 つのドメインのどこにも属さ ない。そもそも, ウイルスは生物か無生物かという議論をも 尽きていない。このように, 細菌とウイルスは似て非なるも のであるが, ともに人に対して感染症を誘発する。

ウイルスは, DNA あるいはRNA を核酸として持ち, その 核酸は夕ンパク質の殼であるカプシドに包まれ，多くはさら に脂質や糖を含むタンパク質の被膜であるエンベロープに覆 われている(図 1)。代表的な非エンベロープウイルスとして ノロウイルス, また, エンベロープウイルスとしてインフル エンザウイルスがあげられる。ウイルスは, 正二十面体やら せん状などの構造をしており, その大きさは一般的に数 10

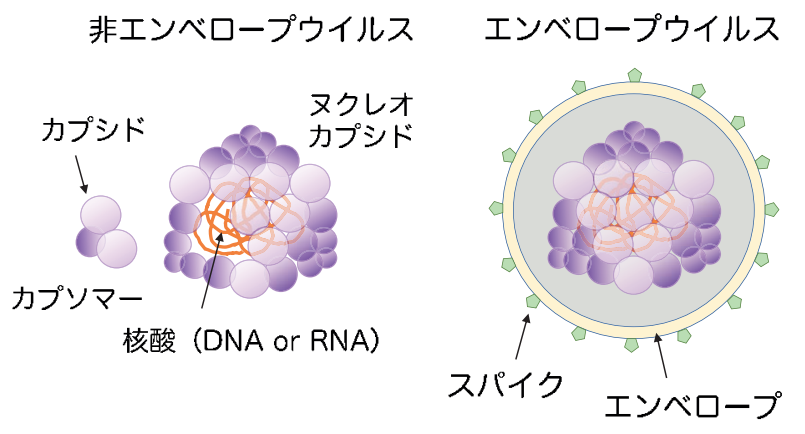

図 1 ウイルスの構造 
から数 $100 \mathrm{~nm}$ であり, 細菌の $1 / 10$ から $1 / 100$ 程度と極めて 小さい。ウイルスは, 細菌と異なり代謝やエネルギ機構は持っ ていないため, 細胞外では単に物質としてのウイルス粒子 (ビ リオン)として存在する。しかし，一旦細胞に侵入(感染)す ると急激に活動し始め, 膨大な数の子ウイルス（1個のウイ ルスから半日で $10^{6}$ 個)を産生する。ウイルス粒子は，特定 の細胞表面の受容体タンパク質に吸着して細胞内に侵入し, カプシドが分解することで内部の核酸が細胞質中に露出(脱 殼)し，この暗黒期の間に核酸の複製やタンパク質の合成が 行われ，これらが組み立てられて子ウイルスとなり細胞外に 放出 (1 個のウイルスからおよそ $10^{5}$ 個)される。

原核生物である細菌(バクテリア)の原核細胞には，真核細 胞に見られる核膜やミトコンドリアなどの器官はなく，主に， DNA 繊維からなる核様体, リボソーム, 細胞質, 細胞膜, 細胞壁などにて構成される(図 2)。感染症診断の検査に必須 のグラム染色による分類におけるグラム陰性菌では, 細胞壁 の外側に外膜がある。細胞膜や外膜は脂質二重膜, 細胞壁は ペプチドグリカンが主成分となる。また，菌種によっては， 細胞壁の外側に粘着物質の層である，主に多糖類からなる萊 膜を作る。細菌は, 一般的に数 $100 \mathrm{~nm}$ から数 $\mu \mathrm{m}$ の大きさ であり, 球状や桿状の形状を持つ。細菌によっては, 外部器 官として鞭毛・繊毛や線毛が表層に付属する。細菌は，その 細胞が 2 分裂することによって増殖する。一般的な病原細菌 は，20〜30 分に 1 回のペースで分裂し，6 時間で $10^{5}$ 個台ま で増えるため, 栄養条件が整った環境で放置されると大量に 増殖することになり, 産生した毒素による細胞傷害(細菌感 染)を引き起こしてしまう。

水と触れ合う固体表面に細菌の活動によって形成される粘 着性の膜状物質(いわゆる, ぬめり)は, バイオフィルムと呼 ばれ，多種多様な微生物がお互いに作用し合う共同体となっ ている。バイオフィルムの中では, 細菌などの微生物の集団 が，さまざまなポリ多糖，タンパク質，糖タンパク質，糖脂 質, 細胞外 DNA, 水分から作られた構造体(細胞外重合物質：
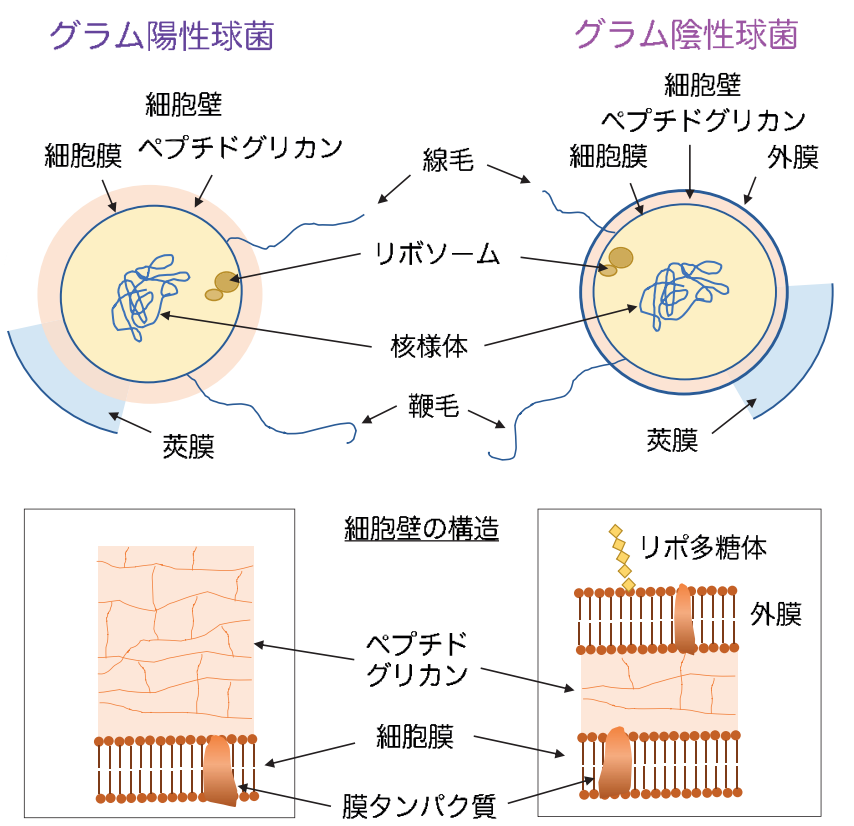

図 2 細菌の構造
EPS)の中で生息している。バイオフィルムが材料表面に形 成されるサイクルは, 次の 4 つのステージで説明されること が多い(図 3 参照)。各種の有機物・無機物から形成されるコ ンディショニングフィルムに細菌が初期付着する(1)開始期, 細菌同士が相互作用しコミュニケーションを成立させていく (2)成熟期，代謝活動が活発となる(3)維持期，そして，一部が 崩壊して細菌を浮遊菌として放出する(4)分解期というプロセ スである。バイオフィルムが形成されると，それが内部に生 息する細菌を物理的にも化学的にも保護し, 生存に適した環 境が提供されることとなる。

\section{3．細菌・ウイルスの表面での様態}

ウイルスは，宿主である細胞の中にいる間は「生きて」い るが，細胞の外に出てモノの表面に付着したとしても太陽の 紫外線などにてすぐに不活化される(感染性が失われる)。熱 にも弱く, $60{ }^{\circ} \mathrm{C}$ では数秒で感染力が半減する。インフルエ ンザウイルスのようなエンベロープウイルスは，アルコール や洗剤にても容易に不活化される。しかし，エンベロープウ イルスでも，そのような環境に置かれない限り，さまざまな 材料上で数時間から数日まで感染力が維持されることが，コ ロナウイルスによる調査により判明している ${ }^{1), 2)}$ 。COVID-19 を引き起こしているコロナウイルス (SARS-CoV-2) は, その 生存期間として, プラスチックで 3 日, ステンレススチール で 2 日，銅で 4 時間などと報告された ${ }^{3)}$ 。食中毒を引き起こ すノロウイルスは, エンベロープのないウイルスであるため アルコールでは死滅しないだけでなく, 食品が接触するさま ざまな材質 (セラミックス, 木, ゴム, ガラス, ステンレス スチール，プラスチック)の表面で，室温において 28 日間も その感染力が残っていることが報告されている4

細菌は，ウイルスとは異なり，モノの表面に付着した場合 も環境条件が揃えば単独で増殖が可能である。しかも非常に 厄介な問題として, 細菌自身が, 産生する多糖類などを周囲 に張り巡らし，短時間のうちに細菌同士が協働したバイオ フィルムを形成する(図 3)。一旦表面上に形成されたバイオ フィルムは, 環境からの物理的化学的な妨害から細菌を保護 することになる。具体的には，バイオフィルムは，流れ環境 下での細菌の分離を防御したり, 内在性医療器具においては 食細胞の捕食に対し物理的に防御バリアとなったりと，非常 に幅広い役目を持つ。さらに，さまざまな外部環境刺激に対 し周囲の細菌同士で化学物質を用いた情報伝達が行われ, 細 菌集合体として機能するクオラムセンシングと呼ばれる細胞 間コミュニケーションシステムが働いていることがわかって いる。

\section{4. 抗菌・抗ウイルス・抗バイオフィルムのための 材料表面設計}

我々が日常行っている，石鹸で手を洗う，生ものを加熱調 理する，アルコール消毒する，といったことは，抗菌や抗ウ イルス対策として有効な手段であるが，モノ(材料)の表面自 体にその効果を持たせるものではない。抗菌や抗ウイルスの ための材料表面を設計するためには, そのような機能をあら かじめその表面に持たせるような処理を施すことが必要にな 


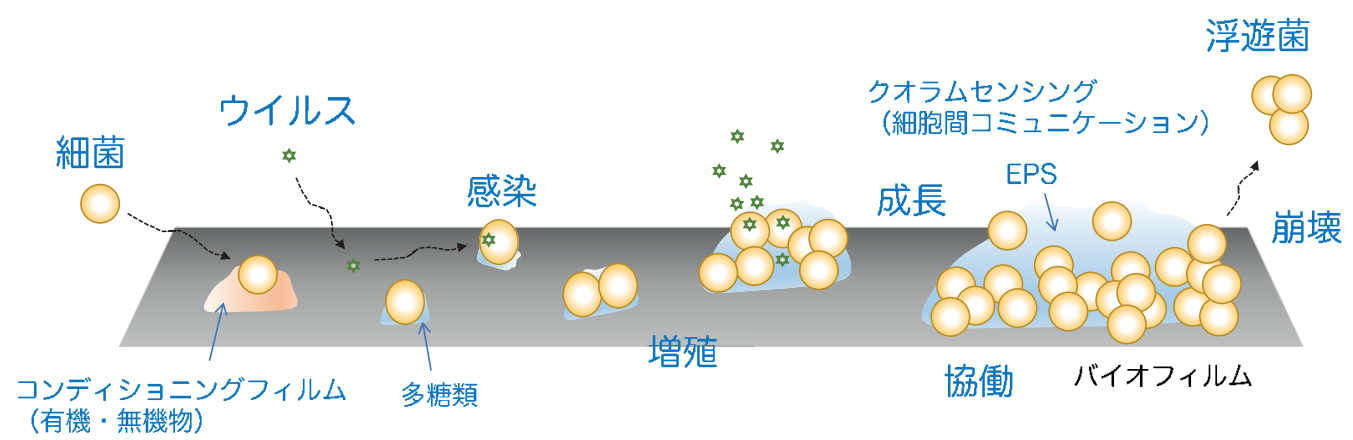
開始期
成熟期
維持期
分解期

図 3 細菌・ウイルス・バイオフィルムの表面での様態

る。抗菌すなわち細菌の増殖を防ぐための最良の戦略は，材 料表面への細菌の初期付着を抑制することであり, 細菌が付 着できないような表面，あるいは，付着したとしても短時間 に細菌が死滅する表面を作り出すことにある。ウイルスは, 材料表面では増殖はしないが, 前述のように感染力を保持し たまま長期間存在することが問題となるため, 細菌と同様な 戦略をとることが有効であろう。初期段階となる細菌の付着 を抑制することで，バイオフィルムまで発展させることを防 ぐことができる。それでは, 細菌やウイルスの初期付着を抑 制することができる表面は，どのような指針で設計すればよ いのか。それは, (1)殺菌・不活化効果のある表面, および, (2) 付着防止効果がある表面を作り出すことにある。

\section{1 殺菌・不活化効果のある表面}

殺菌・不活化効果のある表面とは, 殺菌性やウイルスの不 活化性のある因子が固定された表面であり，これにより細菌 やウイルスの初期付着を抑制する。これを実現するために, 数多くの因子とそのさまざまな固定化方法が提案されている。 抗菌剤として実績のあるトリクロサン, 消毒薬として有効な 塩化ベンザルコニウムなどのさまざまな有機系抗菌剤は, グ ラフト重合などにて固定化される。第三級アミンやN-ハラ ミンといった官能基を有する多様な抗菌性ポリマーコーティ ング, さらに, 活性酸素種や一酸化窒素, 活性窒素種といっ た細胞機能に傷害を与える分子を産生あるいは徐放するポリ マーコーティングが研究・開発されている。無機物質として は, 銀や銅などのいわゆる抗菌性の金属が, 薄膜やナノ粒子 として含有されたコーティングといった形態で, 広範な用途 で長く利用されている。抗ウイルスコーティングにも, この ような金属の効果を利用したものが多く開発されている。ま た, 光触媒酸化チタンは, 光照射が必要なものの, 活性酸素 を利用した強力な殺菌・ウイルス不活性化の因子である。バ ンコマイシンなどの抗生物質を徐放することができるコー ティングも有効な手段である。その他にも, エッセンシャル オイルなどの自然由来殺菌成分など, さまざまな固定用の因 子が研究されている。

銀イオンの強力な抗菌効果は, 黄色ブドウ球菌, 表皮ブド ウ球菌, 緑膿菌, 大腸菌, 肺炎桿菌など多種類の細菌で実証 されている。ここで, 銀の抗菌メカニズムについて少し触れ ると, ほぼ以下のように説明される。銀ナノ粒子が放出した
銀イオンおよび産生した活性酸素が, 細菌細胞の細胞膜破壊, タンパク質変性による機能傷害および DNA 破壊を引き起こ す。これらは, 細胞内部からも細胞膜や膜タンパク質を攻撃 し，さらに，細胞質成分と核酸に相互作用することでタンパ ク質や酵素の変性や DNA の切断を誘発する。また, 銀イオ ンは, 硫黄, りん, 酸素, 窒素を含む電子供与体に作用し, 呼吸反応連鎖酵素などを阻害したりする。活性酸素の抗菌・ 抗ウイルス効果のメカニズムについては, おおよそ以下のよ うに説明される。活性酸素であるヒドロキシルラジカル $(\cdot \mathrm{OH})$, スーパーオキシドラジカルイオン $\left(\cdot \mathrm{O}^{2-}\right)$, 過酸化水 素 $\left(\mathrm{H}_{2} \mathrm{O}_{2}\right)$ が, 細菌細胞にさまざまな酸化ストレスを誘導する。 ヒドロキシルラジカルは, 脂質からなる細胞膜に脂質過酸化 反応を誘導し傷害を与える。過酸化水素は, 細胞内でヒドロ キシルラジカルを生成させ, タンパク質の変性, 核酸の分解, 酵素の失活などの致死的な傷害を与える。これらにより, 細 菌が死滅することになる。一方, ウイルス粒子については, エンベロープの有無により, 活性酸素の効果は異なってくる。 エンベロープを持つウイルス粒子は, エンベロープが脂質や 糖タンパク質で構成されており, 細菌細胞と同様にヒドロキ シルラジカルとの酸化反応により, 機能傷害を与えることが できる。しかし, エンベロープを持たないウイルス粒子につ いては, カプシドを構成するタンパク質には脂質は含まれて おらず，ヒドロキシルラジカルによる過酸化反応を利用する ことができない。このようなウイルスの不活化には, 高温度 や次亜塩素酸ナトリウム (強塩基) などの手段が用いられるが, これによって引き起こされるタンパク質の変性については, ヒドロキシルラジカルによっても可能である。

\section{2 付着防止効果のある表面}

細菌やウイルスが表面に付着し定着をする際には，物理・ 化学的な原理・現象だけでなく生物的な要因が影響する。こ こでは，それを直接要因と間接要因に分けて説明する(表 1)。 直接要因には, 材料表面の形態と物理化学特性があげられる。 表面形態は, そのマイクロ・ナノレベルの差異が, 細菌・細 胞の接着に大きな影響を及ぼす。多孔性の表面は, その相対 的なサイズにより, 細菌が付着したときのアンカーとして働 くことで接着性が増す場合がある。バイオマテリアルとして 使われる多孔質のハイドロキシアパタイトは, 逆にこの特性 を使い細胞接着性を高めている。材料表面の物理化学特性と 
表 1 細菌の付着・定着に影響する因子

\begin{tabular}{|c|c|}
\hline \multicolumn{2}{|l|}{ 直接要因 } \\
\hline 表面形態 & $\begin{array}{l}\text { 多孔性(マクロ・マイクロサイズ) } \\
\text { 表面粗さ(マイクロ・ナノレベル) }\end{array}$ \\
\hline 物理化学特性 & $\begin{array}{l}\text { 表面エネルギ } \\
\text { 親水性／超親水性, 撥水性／超撥水性 } \\
\text { 官能基(疎水性, 極性, 電荷, 水和) }\end{array}$ \\
\hline \multicolumn{2}{|l|}{ 間接要因 } \\
\hline 環境要因 & $\begin{array}{l}\text { 電解質, } \mathrm{pH}, \text { 温度 } \\
\text { ホスト細胞タンパク質・接着因子 } \\
\text { 流体のせん断速度, 粘度, 流速 }\end{array}$ \\
\hline 病原体 & $\begin{array}{l}\text { グラム陽性 /陰性, 属・種 } \\
\text { 細菌の形状 } \\
\text { 表面エネルギ(細菌の) } \\
\text { 発現接着因子 }\end{array}$ \\
\hline
\end{tabular}

して, 表面エネルギや親撥水性, 付与している官能基の性状 (疎水性, 極性, 電荷, 水和性など)が, 付着に及ぼす因子に なる。バイオフィルムについても, 細菌付着の安定性が, 材 料の表面構造や化学組成, 表面エネルギによって異なってく る。また, 間接要因には, 周囲環境の物理・化学的事象や付 着する細菌などの様態などがあげられる。周囲環境に関わる 因子としては，表面に接する溶液の温度, $\mathrm{pH}$, 化学成分だ けでなく，その流動状態に関わる因子として，流速，せん断 力, 粘度などが, 直接的に影響する。細菌の種類 (グラム陽性・ 陰性, 属や種) や形状 (球状, 桿状), 外部器官としての鞭毛. 繊毛や線毛の有無などは，それが表面に付着するかどうかを 決定する重要な因子となる。さらに, 細菌についても, その 表面エネルギや疎水性, 電荷などが, 表面との相互作用の程 度を規定することにつながる。

それでは，このようなさまざまな直接・間接要因に対して， 細菌やウイルスの材料表面への付着を防止する方法として, どのような表面設計指針が考えられるであろうか。それには， 表面の形態をアレンジすること(物理的側面)やタンパク質の 吸着を抑制すること (化学的側面)が主要な柱となる。図 4 に, その具体的な項目を並べたが，物理的側面としては，ナノレ ベルの表面構造や平坦性, 適切なマイクロ・ナノレベルの構 造の形成，特定のマイクロナノパターンの形成など，化学的
側面としては, タンパク質の表面相互作用の低減, 吸着速度 の低減などがあげられる。

後者を理解するためには, 材料表面へのタンパク質の吸着 現象について知る必要がある。人工物が生体内に埋め込まれ た際など, 細胞が材料表面に触れるときには, その界面に細 胞外マトリクスを構成するコラーゲンなどの細胞接着性タン パク質が介在する。これらのタンパク質がまず人工物表面に 吸着した後, 細胞が付着・接着し, 活性化して増殖するとい う経過を辿る。これらのタンパク質は, 細胞自らも産生し, 自己の表面での接着をより強固なものにしていく。同じよう な現象は, 細菌においても見られる。細菌は, 材料表面に付 着した環境中のタンパク質や多糖類を含む有機物や無機物か らなるコンディショニングフィルムを介し接着していく。ま た，細菌は，接着因子を認識する表面成分を自らが産生して， 細胞接着性夕ンパク質と相互作用することで, その接着が促 進されていく。したがって，材料表面の有機物，とりわけ夕 ンパク質の初期吸着をコントロールすることが細菌の付着を 防止する上で非常に重要になる。

以上の物理的・化学的側面から見た表面設計のパラメータ となる特性として, 表面自由エネルギや表面電荷, ナノレベ ルの立体構造があげられる。ただし, 生きた細菌細胞の基本 的な挙動は，その付着した表面の特性だけでなく，細胞と表 面間に存在する媒体の特性に大きく依存することを念頭にお いておく必要がある。つまり，媒体が細菌や材料表面の特性 双方に大きな影響を及ぼす。すなわち, 細菌と材料の表面自 由エネルギや電荷は，触れている溶液の $\mathrm{pH}$ に依存し，また， さまざまな特性をもつタンパク質の表面への吸着構造が空間 的・時間的に動的変化することによって大きく影響を受ける。 このように複雑な現象となることから，特定の限られた因子 のみで付着現象を説明することは困難であることを，付着防 止効果を持つ表面を設計するにあたって, 十分に理解してお く必要がある。

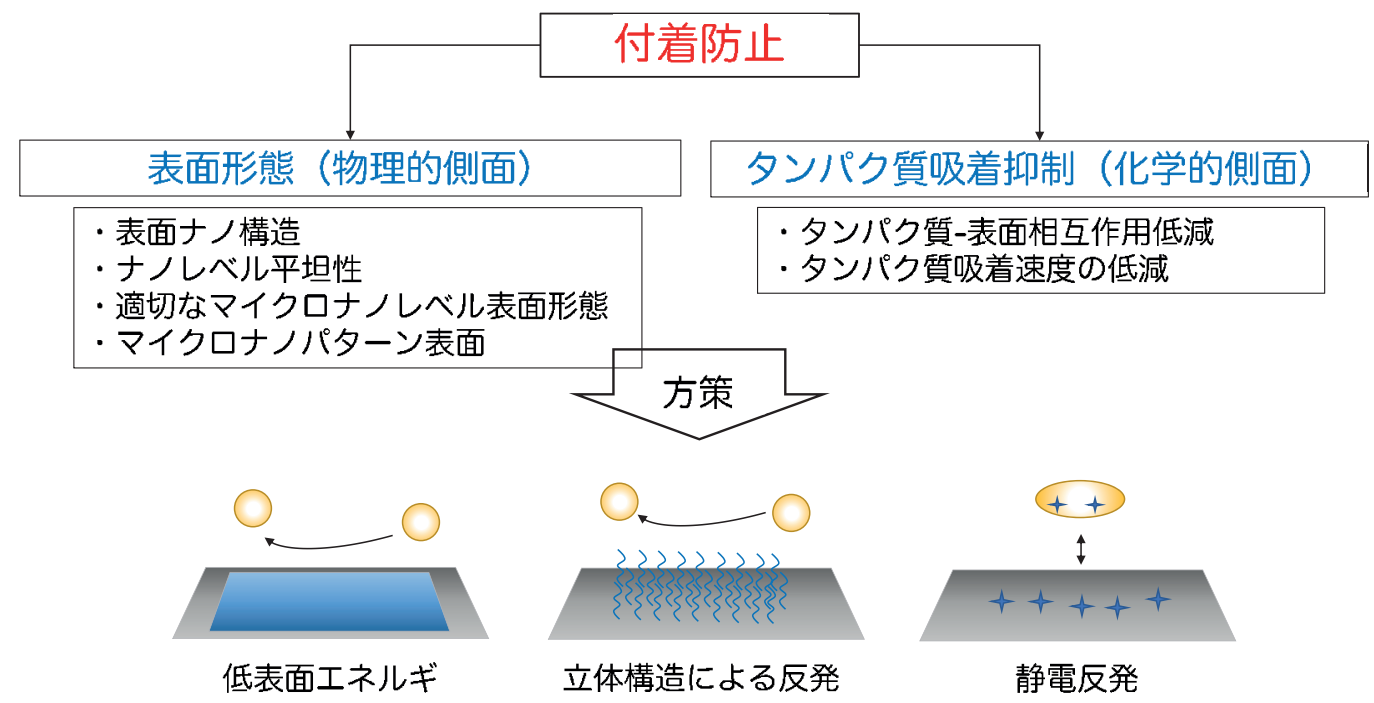

図 4 付着防止効果付与の方策 


\section{5. 抗菌・抗ウイルス・抗バイオフィルムのための 表面処理}

細菌やウイルスの増殖抑制のための表面処理に関する研究 が, これまで数多く実施されてきた。ここでは, その動向が わかるように，なるべく多くを紹介したい。

\section{1 細菌・ウイルスの増殖抑制}

5. 1.1 殺菌・不活化効果のある表面

銀などの抗菌金属を利用し材料表面に殺菌・不活化効果を 付与する場合, スパッタリング法やプラズマ化学気相成長 (CVD) 法あるいはゾルゲル法などを用い, 薄膜状あるいは ナノ粒子状として定着する方法が用いられる。これらの方法 により, より少ない体積 (量)でより大きな表面が得られ, そ れらのイオンの抗菌効果を効率的に利用することができる。 25-50 nm サイズの銀ナノ粒子が TiN 薄膜に分散したナノコ ンポジット TiN/Ag 薄膜が, マグネトロンスパッタリング法 にて形成され，これにより緑膿菌や黄色ブドウ球菌の増殖が 抑制されたことが報告されている ${ }^{5)}$ 。また，同時マグネトロ ンスパッタリング法によって得られた銀含有ハイドロキシア パタイトコーティングが, 表皮ブドウ球菌や黄色ブドウ球菌 を大幅に減少させることができることが示された ${ }^{6)}$ 。プラズ マ CVD 法は，スパッタリング法などとの併用により，ナノ 粒子が分散含有された有機無機の各種薄膜の形成が可能であ る。Korner らは, 炭化水素系ガスを原料とした RF プラズマ CVD 法と銀の同時スパッタリングにより, 銀ナノ粒子が分 散含有されたナノコンポジット有機薄膜を形成したことを報 告している ${ }^{7)}$ 。炭素系硬質膜であるダイヤモンドライクカー ボン (DLC)をマトリックスとし銀ナノ粒子を含有させたプラ ズマ CVD 薄膜が, 大腸菌に対し抗菌性を示したことが報告 されている ${ }^{8)}$ 。ゾルゲル法では, 銀ドープ有機無機ハイブリッ ドコーティングがバイオマテリアルであるポリエチレンやポ リ塩化ビニル上に形成され，大腸菌や黄色ブドウ球菌への抗 菌効果が確認されている ${ }^{9)}$ 。特定のウイルスの不活化に対す る銀の効果について, 多数報告されている。 Lu らは, 銀ナ ノ粒子が B 型肝炎ウイルスの RNA の生産や細胞外へのビリ オンの放出を阻止できることを報告している ${ }^{10)}$ 。また, Rogersらは, サル痘ウイルスの感染を銀ナノ粒子が防ぐこ とを, ビトロにおいて確認している ${ }^{11)}$ 。今後は, より広域 スペクトルで持続性のある抗ウイルス表面処理技術の開発が 待たれる。

光触媒酸化チタンについては, ナノ粒子がコロイド分散し たコーティング溶剤として開発されており，塗膜として使用 することで抗菌だけでなく防污, 脱臭などのさまざまな用途 に使用されているが，各種 CVD 法やスパッタリングなどの 物理気相成長 (PVD) 法による薄膜コーティングについても多 数の報告がある。近年では, さらに高機能化を目指した研究 として，さまざまな他の物質との複合化がなされている。 CVD 法により形成された酸化チタンと酸化銅の多層膜は, 紫外線照射により, 大腸菌の死滅とその後の細菌の表面から の離脱を誘導する機能(セルフクリーニング)を持つことが, Yates らにより示されている ${ }^{12)}$ 。コロイド溶液を原料とした プラズマCVD法により, 耐摩耗性に優れる DLC 薄膜中に
酸化チタンナノ粒子を分散含有させた構造が作製され，紫外 線照射により大腸菌に対する抗菌性能が確認されている ${ }^{13)}$ 。 光触媒酸化チタンのウイルスへの効果についても報告がある。 銀をドープした酸化チタンナノ粒子により, 飲料水処理にお いて細菌に感染するウイルス(バクテリオファージ)の不活性 化が確認されている ${ }^{14)}$ 。SARS-CoV-2 に対する酸化チタンコー ティングの効果についても調べられ，速報されている ${ }^{15), 16) 。 ~}$

その他にも,さまざまな種類の材料について調べられている。 植物から得られるエッセンシャルオイルには, 天然の抗菌, 抗ウイルス, 殺菌, 抗炎症成分を含むものがあり, この成分 であるテルピネン 4 オールを利用したプラズマ重合膜が, 黄 色ブドウ球菌, 緑膿菌および表皮ブドウ球菌の付着やバイオ フィルム形成を防いだとする報告がある ${ }^{17)}$ 。カーボンナノ材 料の一つであるフラーレン $\left(\mathrm{C}_{60}\right)$ は, 光増感作用を示し, 光照 射により活性酸素を産生する。この特性を利用した抗ウイルス 作用 ${ }^{18)}$ や抗菌作用 ${ }^{19)}$, また, 細胞毒性(ガン細胞の死滅) ${ }^{20), 21)}$ について報告されている。

5. 1. 2 付着防止効果のある表面

ナノレベルの表面粗さが細菌や細胞の付着に及ぼす影響に 関しては, さまざまな材料について調べられ, 非常に興味深 い結果が得られている。チタンは, 機械特性や環境安定性に 優れ, 特にその高い生体親和性から, バイオマテリアルとし て生体インプラントの材料として用いられている。マグネト ロンスパッタリング法にて形成されたチタン薄膜について, ナノオーダーで変化させた表面粗さ $(\mathrm{Ra}: 1.6,1.2,0.7 \mathrm{~nm})$ が, 黄色ブドウ球菌や緑膿菌の付着やそれらによるEPS の分泌 に大きく影響することが示された ${ }^{22)}$ 。Ivanovaらは, 同様に マグネトロンスパッタリング法で成膜されたナノスケールの 銀薄膜について報告し, 銀イオン濃度が細菌の生存の主要な 決定要因になることの他に, 細菌の付着とパターンはその表 面形態に大きな影響を受けることを示した ${ }^{23)}$ 。培養細胞を 用いた研究では, 表面粗さ $(\mathrm{Ra})$ の大きく異なるシリコンウ エハ上で神経細胞を培養し，10〜 $50 \mathrm{~nm}$ 付近でもっとも細胞 の増殖が見られる一方, ほとんど平坦な表面 $(\mathrm{Ra}$ : 数 $\mathrm{nm})$ や 粗い表面 $(\mathrm{Ra}: 100 \mathrm{~nm}$ 前後)では細胞付着が抑えられること が報告されている ${ }^{24)}$ 。また, DLC が成膜された, 表面粗さ (Rc) 0.03〜 3.5 $\mu \mathrm{m}$ を持つ異なった基板にてマウス筋芽細胞が培養 され， $0.7 \sim 1.0 \mu \mathrm{m}$ の表面粗さにてもっとも細胞の付着や増 殖が大きいことが示された ${ }^{25)}$ 。このように, 表面粗さ依存 性については, さまざまな材質やスケールにて研究が行われ てきているが, 相反する結果が得られるなど, 統一した見解 に至っていないのが現状である。

さらに積極的にマイクロ・ナノスケールのさまざまな形状 を材料表面に形成させ，その細菌の付着防止効果が調べられ ている。バイオミメティックの観点からは, セミの羽が殺菌 性を持つ仕組みについて人工的に作製した表面で解明した研 究 ${ }^{26)}$ が有名である。セミの羽には無数のナノピラー形状 (100 nm 径, $200 \mathrm{~nm}$ 高さ, $170 \mathrm{~nm}$ 間隔)が存在し，そこに付 着した細菌が沈み込み細胞膜が伸長し破れることで殺菌効果 を示すことが説明されている。動植物の表面が, 微生物など の付着を防ぐことは, 鯨, サメ, イルカの肌やハスの葉など にて表面化学やマイクロ・ナノスケールの形態からの理論解 
釈もされてきており, 材料表面の構造をマイクロ・ナノレベ ルで制御して抗菌表面を創製するプラットフォームとも相 まって，盛んに研究が行われている。規則配列したピット (1 $-2 \mu \mathrm{m})$ を有する表面において, 緑膿菌や黄色ブドウ球菌の 付着が促進され，不規則な配列のピットであるとそのような

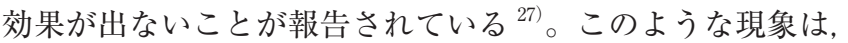
培養細胞でも得られており, 秩序をもって配列したピットと 無秩序な配列のピットを持つ表面で, 間葉系幹細胞の分化に 異なった影響(無秩序で骨細胞に分化)を示すという非常に興 味深い結果が報告されている ${ }^{28)}$ 。さらに, マイクロサイズ の溝が細菌の付着に影響を及ぼすことが報告されている。 $1.3 \mu \mathrm{m}$ 幅で $120 \mathrm{~nm}$ 深さのマイクロ溝が蛍光菌の整列付着を 促進したこと ${ }^{29)}$ ，あるいは，50 nm 深さで $1.6 \mu \mathrm{m}$ 間隔のマ イクロ溝では, 細菌の付着が抑制されたこと ${ }^{30)}$ が示されて いる。マイクロピラー $(5 \mu \mathrm{m}$ 径 $)$ を異なる密度で整列配置し たポリジメチルシロキサン (PDMS) にDLC 薄膜をコーティ ングし，表面に微細な凹凸形状を形成した基板にて，その密 度が大きいほど細胞の付着が抑えられることが報告されてい る ${ }^{31)}$ 。以上のような研究結果は, 細菌のサイズが表面構造 におけるサイズと同等であると, 細菌と表面との接触面積が 最大化する効果が得られ, 細菌の接着ポテンシャルが増加す るという考え方を支持している。さらに，抗バイオフィルム に関して, Fadeevaらは, フェムト秒レーザを用いてチタン 表面にマイクロナノ構造を形成させることで超撥水性とし, この表面が，緑膿菌のコロニー化を抑制したことを報告して いる ${ }^{32)}$ 。また, 細菌の形状の相違が, 表面接触面積の差に つながり，その付着性や EPS 産生能力に違いが生まれること， このことから逆に選択的に細菌の付着を抑制あるいは促進が できるとしている。以上のように，表面の形態のみで細菌や ウイルスの初期付着を防止することができれば，いわゆる抗 菌剤は不要となり，その生体や環境への影響を考えると，メ リットは非常に大きい。

\section{2 抗菌と生体適合性の両立}

抗菌特性を持つことと生体適合性(細胞接着性)を持つこと は, 相反する事象で, 諸刃の剣の関係となる。バイオマテリ
アルにて作られたデバイスをインプラントとして体内に内在 させる場合，そのバイオマテリアルが細胞との親和性がよい 表面をもち, 同時に細菌の増殖やバイオフィルムの成長を抑 えることができる表面であることが重要となる。インプラン トが感染すると, 炎症を生じるばかりか, 交換を余儀なくさ れる恐れもでてきて，QOL が著しく低下する。このような 両立性を担保できるような表面処理についての研究も盛んに 行われている。

アリルアミンを原料としたプラズマ重合により形成したポ リマー層に銀ナノ粒子を結合することで，表皮ブドウ球菌の 付着とバイオフィルム形成を効果的に防ぎ，同時に骨芽細胞 の付着と伸展がサポートされたことが報告されている ${ }^{33)}$ 。 Ewald らは, PVDによって形成された Ti/Ag ハードコーティ ング (約 $0.7-9 \%$ 銀) は，表皮ブドウ球菌や肺炎桿菌への抗 菌特性を示しながら, 骨芽細胞や表皮細胞に対する毒性効果 はなく，抗菌と生体親和性が両立できることを報告した ${ }^{34)} 。$ マグネトロンスパッタリングと陽極酸化処理により作製され た，5-20 nm サイズの酸化銀ナノ粒子が埋め达まれた酸化 チタンナノチューブが, 大腸菌や黄色ブドウ球菌に対する抗 菌性だけでなく, 骨芽細胞との親和性を有し, その伸展, 増 殖，分化に悪影響を及ぼさないことが報告されている ${ }^{35)}$ 。 カーボンナノマテリアルの一つであるグラフェンは，抗菌剤 としてまたバイオマテリアルとして利用できる可能性を有す る興味深い材料である ${ }^{36)}$ 。抗菌剂としては, 大腸菌, クレ ブシエラ菌, ブドウ球菌などに対する効果が明らかになって いる。また, 多種類のヒト細胞に対し, 細胞毒性を示すこと が示されている。これには, グラフェンシートの持つナノレ ベルのシャープなエッジが細菌の細胞膜に損傷を与えると いったメカニズムが提唱されている。その一方で, 材料表面 にグラフェンを平面状態で固定した場合に，間葉系幹細胞の 付着や増殖を促進するといった生体親和性を示すことが明ら かとなっている ${ }^{37)}$ 。

\section{6.おわりに}

図 5 に，これまで述べてきた抗菌性表面処理における方策

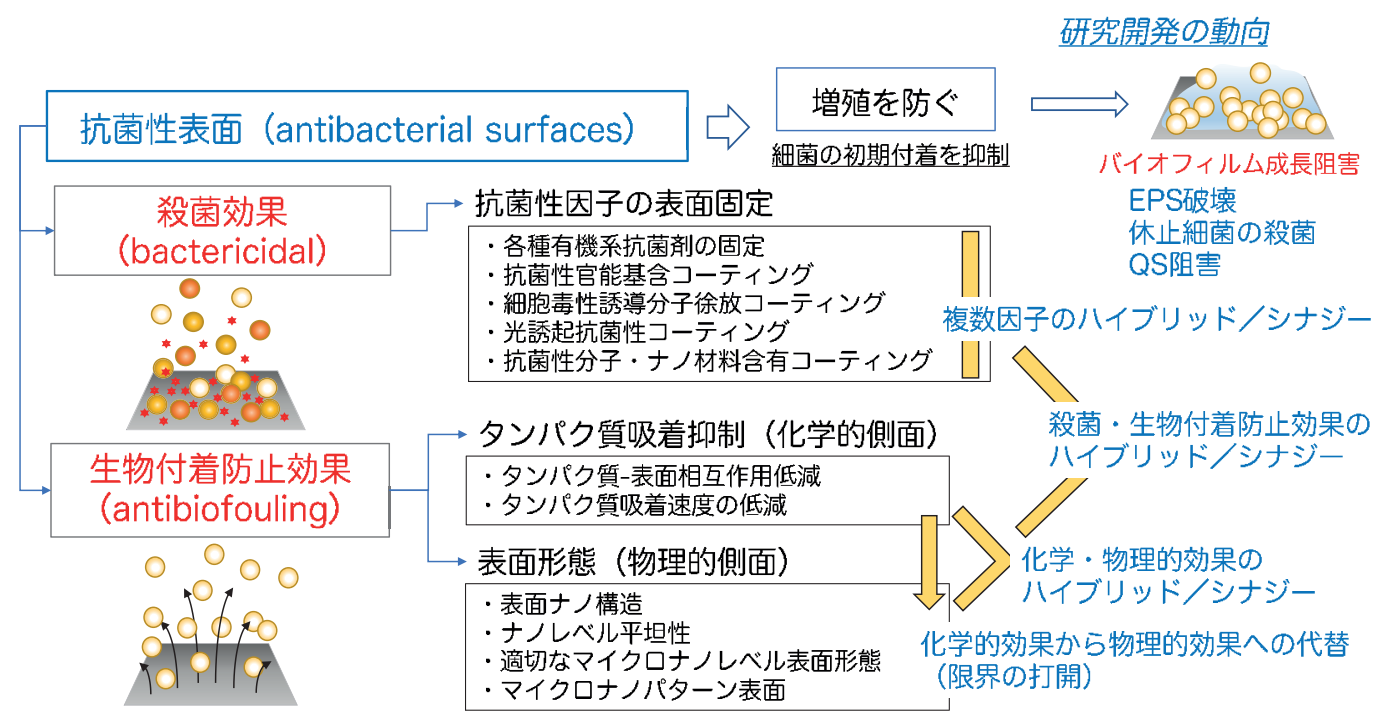

図 5 表面処理技術の整理と研究開発の方向性 
を整理した。また，今後の研究開発の方向性として，複数因 子をハイブリッドすることによりシナジー効果を生み出すこ とができないか，という観点でその組合せなどを示した。さ らに, 今後に向けた課題として, 長期持続性があり, また, 広域スペクトルの抗菌・抗ウイルス特性を示す表面，つまり， 多剂耐性菌や地球温暖化が原因で出現が懸念されている未知 の細菌やウイルスなどを含めた新興・再興感染症にも対処で きる万能な表面をもつ材料が今度開発されていくことを期待 したい。

最後となるが，本稿では，細菌やウイルスを排除する表面 を設計する指針や方策を述べてきたが，我々の生命活動や社 会活動は, 細菌, ウイルス, バイオフィルムとの共存で成り 立っている, ということは忘れてはいけない。ウイルスは, ヒトに感染するたびにその情報をヒトDNA に残し人類に同 化してきている。また，レトロウイルスは，遺伝子治療など になくてはならない材料となっている。また，腸内細菌や皮 膚常在菌は，ヒトの健康維持に欠かせない役割を担っている ことは，よく知られている。さらに，バイオフィルムは，微 生物の機能を利用した環境修復技術として注目されている。 今後世界は, ウイズコロナがますます進み，妥協点を見出し ていく中で新たな発展に向かっていくことになるであろう。 さらに大きく長期的な視点では, 細菌やウイルスは, 地球上 に生息する人類よりずっと多くの数が存在していることを考 えると, ウイズウイルス, ウイズ細菌, ウイズバイオフィル ムを標榜し，一緒にうまくやっていくということが, SDGs にも合致した本来の技術の姿なのかもしれない。

(Received March 22, 2021)

\section{文献}

1 ) G. Kampf, D. Todt, S. Pfaender, E. Steinmann ; J. Hosp. Infect., 104, 246 (2020).

2 ) L. Fiorillo, G. Cervino, M. Matarase, C. D'Amico, G. Surace, V. Paduano, M. T. Fiorillo, A. Moschella, A. L. Bruna, G. L. Romano, R. Laudicella, S. Baldari, M. Cicciu ; Int. J. Environ. Res. Public Health, 17, 3132 (2020).

3 ) N. V. Doremalen, D. H. Morris, M. G. Holbrook, A. Gamble, B. N. Williamson, A. Tamin, S. I. Gerber, J. O. Lloyd-Smith, E. de Wit, V. J. Munster; N. Engl. J. Med., (2020).

4 ) A-N. Kim, S. Y. Park, S-C. Bae, M-H. Oh, S-D. Ha ; Food Environ Virol, 6, 182 (2014).

5 ) P. J. Kelly, H. Li, K. A. Whitehead, J. Verran, R. D. Arnell, I. Iordanova ; Surf. Coat. Technol., 204, 1137 (2009).

6 ) W. Chen, Y. Liu, H. S. Courtney, M. Bettenga, C. M. Agrawal, J. D. Bumgardner, J. L. Ong ; Biomaterials, 27, 5512 (2006).

7 ) E. Korner, M. H. Aguirre, G. Fortunato, A. Ritter, J. Ruhe, D. Hegemann ; Plasma Process Polym., 7, 619 (2010).

8 ) F. R. Marciano, L. F. Bonetti, L. V. Santos, N. S. Da-Silva, E. J. Corat, V. J. Trava-Airoldi ; Dia. Relat. Mater, 18, 1010 (2009).

9 ) M. Marini, S. D. Niederhausern, R. Iseppi, M. Bondi, C. Sabia, M. Toselli, F. Pilati ; Biomacromolecules, 8, 1246 (2007).

10) L. Lu, R. W. Sun, R. Chen, C-K. Hui, C-M. Ho, J. M. Luk, G. KK. Lau, C-M. Che ; Antiviral Therapy, 13, 253 (2008).
11) J. V. Rogers, C. V. Parkinson, Y. W. Choi, J. L. Speshock, S. M. Hussain ; Nanoscale Res Lett., 3, 129 (2008).

12) H. M. Yates, L. A. Brook, I. B. Ditta, P. Evansa, H. A. Foster, D. W. Sheel, A. Steele ; J. Photochem. Photobio. A, 197, 197 (2008).

13) M. Ban, N. Hasegawa; Dia. Relat. Mater, 25, 92 (2012).

14) M. V. Liga, E. L. Bryant, V. L. Colvin, Q. Li ; Water Research, 45, 535 (2011).

15) P. Mlcochova, A. Chadha, T. Hesselhoj, F. Fraternali, JJ. Ramsden, RK. Gupta ; bioRxiv preprint doi: https://doi.org/10.1101 /2020.12.08.415018.

16) S. Khaiboullina, T. Uppal, N. Dhabarde, V. R. Subramanian, S. C. Verma ; viruses, 13, 19 (2021).

17) K. Bazaka, M. V. Jacob, V. K. Truong, F. Wang, W. A. A. Pushpamali, J. Y. Wang, A. V. Ellis, C. C. Berndt, R. J. Crawford, E. P. Ivanova ; Biomacromolecules, 11, 2016 (2010).

18) F. Käsermann, C. Kempf ; Rev. Med. Virol, 8, 143 (1998).

19) H. Aoshima, K. Kokubo, S. Shirakawa, M. Ito, S. Yamana, T. Oshima ; Biocont. Sci., 14, 69 (2009).

20) M. Ban, F. Sasaki ; World J. Nano Sci. Eng., 2, 110 (2012).

21) M. Ban, Y. Kogi, F. Sasaki ; J. the Imaging Society of Japan, 51, 496 (2012).

22) E. P. Ivanova, V. K. Truong, J. Y. Wang, C. C. Berndt, R. T. Jones, I. I. Yusuf, I. Peake, H. W. Schmidt, C. Fluke, D. Barnes ; R. J. Crawford; Langmuir, 26, 1973 (2010).

23) E. P. Ivanova, J. Hasan, V. K. Truong, J. Y. Wang, M. Raveggi. C. Fluke. R. J. Crawford ; Appl. Micro. Biotec., 91, 1149 (2011).

24) Y. W. Fan, F. Z. Cui, S. P. Hou, Q. Y. Xu, L. N. Chen, I.-S. Lee ; J. Neurosci. Met. 120, 17 (2002).

25) M. Ban, S. Tobe, L. Takeuchi ; Dia. Relat. Mater, 90, 194 (2018).

26) E. P. Ivanova, J. Hasan, H. K. Webb, V. K. Truong, G. S. Watson, J. A. Watson, V. A. Baulin, S. Pogodin, J. Y. Wang, M. J. Tobin, C. Lobbe, R. J. Crawford ; Small, 8, 2489 (2012).

27) K. A. Whitehead, J. Colligon, J. Verran ; Colloids and Surfaces B, 41, 129 (2005)

28) M. J. Dalby, N. Gadegaard, R. Tare, A. Andar, M. O. Riehle, P. Herzyk, C. D. W. Wilkinson, R. O. C. Oreffo ; Nature Mater., 6, 997 (2007).

29) C. Díaz, M. C. Cortizo, P. L. Schilardi, S. G. G. de Saravia, M. A. F. L. de Mele; Materials Research, 10, 11 (2007).

30) L. Ploux, K. Anselme, A. Dirani, A. Ponche, O. Soppera, V. Roucoules ; Langmuir, 25, 8161 (2009).

31) Y. Rahmawan, K-J. Jang, M-W Moon, K-R. Lee, K-Y Suh ; BIOCHIP JOURNAL, 3, 143 (2009).

32) E. Fadeeva, V. K. Truong, M. Stiesch, B. N. Chichkov, R. J. Crawford, J. Wang, E. P. Ivanova ; Langmuir, 27, 3012 (2011).

33) K. Vasilev, V. Sah, K. Anselme, C. Ndi, M. Mateescu, B. Dollmann, P. Martinek, H. Ys, L. Ploux, H. J. Griesser ; Nano Lett., 10, 202 (2010).

34) A. Ewald, S. K. Glückermann, R. Thull, U. Gbureck ; BioMed. Eng. Online., 5, 22 (2006).

35) A. Gao, R. Hang, X. Huang, L. Zhao, X. Zhang, L. Wang, B. Tang, S. Ma, P. K. Chu ; Biomaterial, 354223 (2014).

36) A. B. Seabra, A. J. Paula, R. de Lima, O. L. Alves, N. Duran ; Chem. Res. Toxico., 27, 159 (2014).

37) M. Ban, R. Shimoda, Y. Okigawa, M. Ishihara ; Dia. Relat. Mater., 111, 108229 (2021). 